Th1s report was prepared as an account of Government sponsored work. Ne1ther the United States, nor the Commission, nor any person acting on behalf of the Commission:

A. Makes any warranty or representation, expressed or Imp.lied, with respect to the accuracy, completeness, on usefulness of the information contained in this report, or that the use of any information, apparatus, method, or process disclosed in this report may not infringe privately owned rights; or

B. Assumes any liabilities with respect to the use of, or for damages resulting from the use of any information, apparatus, method, or process disclosed in this report.

As used in the above, "person acting on behalf of the Commission" Includes any employee or contractor of the Commission, or employee of such contractor, to the extent that such employee or contractor of the Commission, or employee of such contractor prepares, disseminates, or provides access to, any information pursuant to his employment or contract with the Commission, or his employment with such contractor. 


\section{SPECIAL DISTRIBUTION}

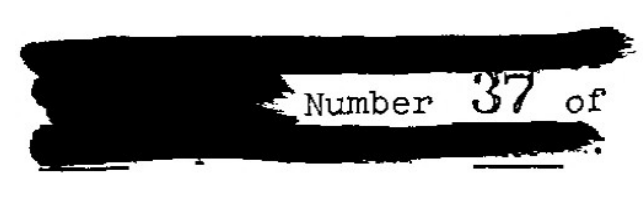

\section{THE ADAPTATION OF AN ION EXCHANGE PROCESS TO REMOTE OPERATION \\ IN A RADIOCHEMICAL SEPARATIONS PLANT}

\section{by}

William J. Mottel and John F. Proctor

September 1961

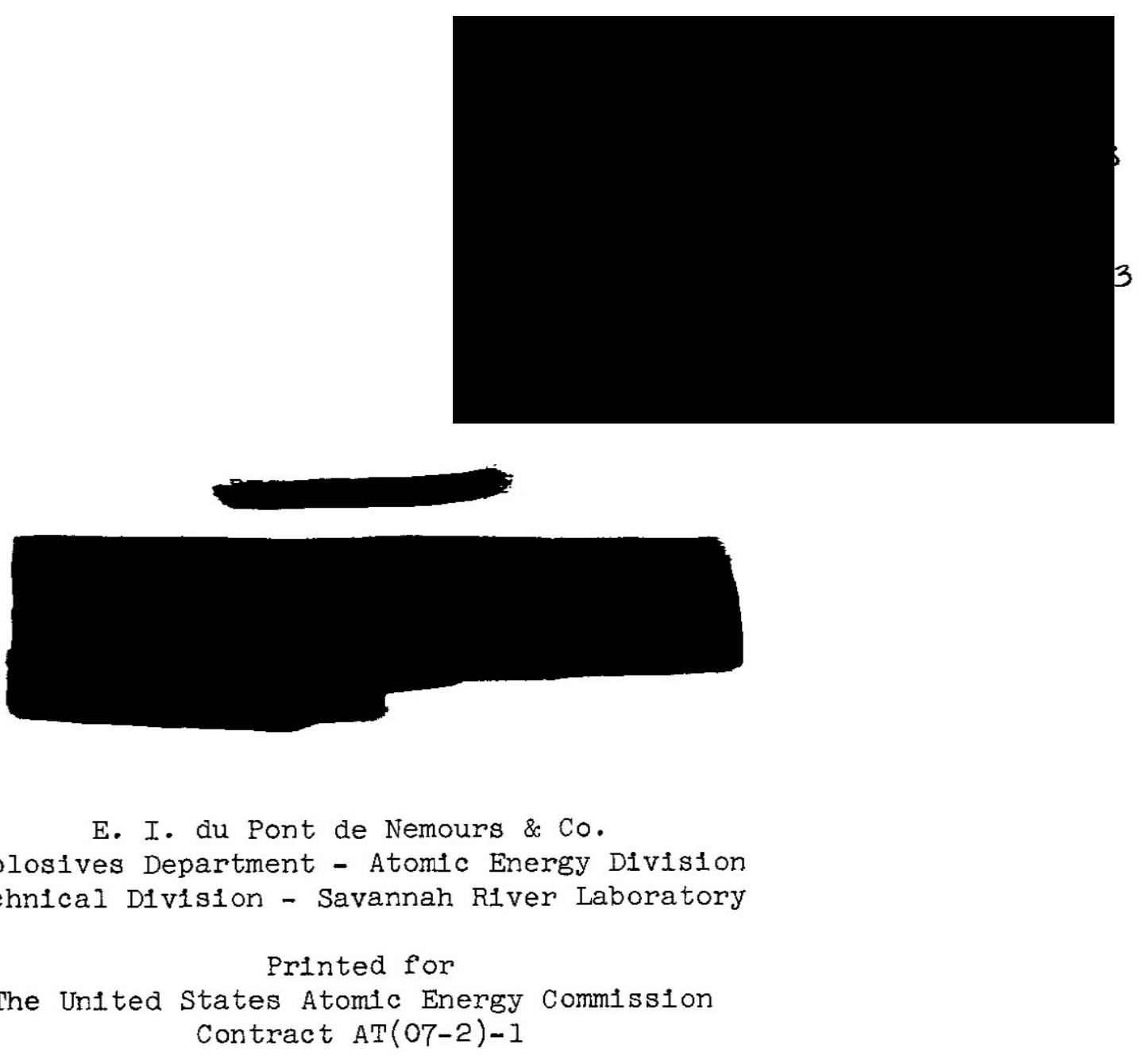

Approved by

W. E. Winsche, Research Manager

Separations Engineering Division 


\section{ABSTRACT}

Equipment and techniques are described for the adaptation of a small-scale ion exchange process to remote operation in a large radiochemical separations plant.

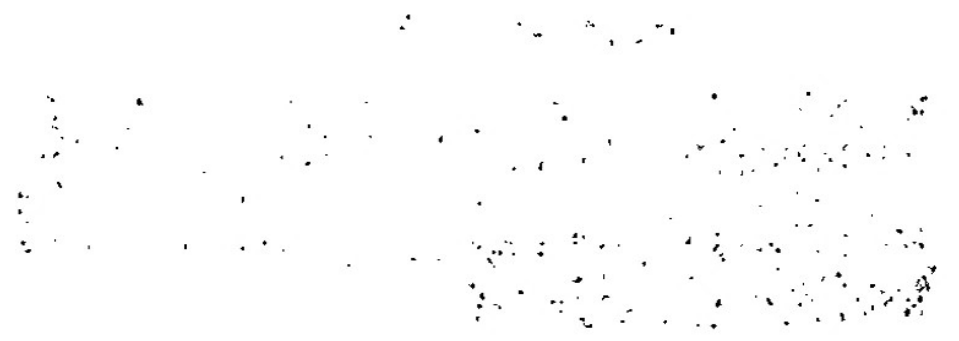

$\therefore \quad \because$ 
$D P-620$

\section{DISTRIBUTION}

Copy No.

1-5. AEC, SROO

6-52. du Pont Company, Atomic Energy Division

53. Albuquerque Operations office

54. Atomic Energy Commission, Washington

55. Chicago Patent Group

56. General Electric Company, Richland

57. Hanford Operations office

58. Lawrence Radiation Laboratory (Livermore)

59. Los Alamos Scientific Laboratory

60. Mound Laboratory

61. Oak Ridge Operations Office

62. Patent Branch, Washington

63. Phillips Petroleum Company (NRTS)

64. San Francisco Operations Office

65. Union Carb1de Nuclear Company (ORGDP)

66. Union Carbide Nuclear Company (ORNL)

67-106. Technical Information Service Extension 


\section{CONTENTS}

$\underline{\text { Page }}$

Introduction

Summary 4

Discussion 5

Simplified Process Description 5

The Equipment Frame 6

The Ion Exchange Column 12

The Prototype Unit 14

Appendix - Description of Auxiliary Equipment 15

1. Service Piping 15

2. Process Vessels 15

3. Alr Lifts 18

4. Vessel Venting and Entrainment 19

Bibilography 20

\section{LIST OF FIGURES}

\section{F1gure}

$1 \quad$ Process Flow Diagram 7

$2 \quad$ Equipment Frame Structure 9

$3 \quad$ Plan View of a Complete Equipment Frame 10

$4 \quad$ Elevation View of a Complete Equipment Frame 11

5 A Typical Ion Exchange Column 13

Appendix

A-1 Filter 16

A-2 Target Dissolver 17

A-3 Typical Air Lift and Separator 18 


\title{
THE ADAPTATION OF AN ION EXCHANGE PROCESS TO REMOTE OPERATION IN A RADIOCHEMICAL SEPARATIONS PLANT
}

\author{
INTRODUCTION
}

In general, ion exchange processes have advantages over solvent extraction processes when batch operations are indicated; that is, when the quantities of material to be handled are small and the desired product concentrations are high. Conversely, solvent extraction is usually preferred when large quantities of material are to be processed because 1t is readily adaptable to continuous operations. Ion exchange, although extensively used in laboratory radiochemical separations, has not of ten been applied in large production facilities that handle highly radioactive solutions. The limlted application of ion exchange in this field can be attributed to the difficulties associated with the adaptation of these processes to remote operations, principally the problems of handling the solid ion exchange resins. This report describes ion exchange equipment and techniques that have been developed for a specific remote process application, namely, the use of an anion exchange process to recover $\mathrm{Pu}^{238}$ and $\mathrm{Np}^{237}$ from irradiated neptunium oxide target elements.

\section{SUMMARY}

A compact, remotely operated unit was designed for the processing of Irradiated $\mathrm{NpO}_{2}$ target elements to recover both $\mathrm{Pu}^{238}$ and unburned $\mathrm{Np}^{237}$. The equipment needed to separate and decontaminate these isotopes included a dissolver, five ion exchange columns, and eleven valence adjustment and collection tanks complete with instrumentation and solution transfer devices. All of this equipment was mounted within two steel frames, each designed to occupy one shielded module of an existing fuel processing plant. Each frame, complete with its complement of tanks, columns, and piping, was capable of being installed in, or removed from, the module as a single unit. Only those few items subject to periodic fallure could be removed individually from the frame, while the majorlty of the equipment, including tankage and piping, was permanently fastened to the frame structure.

Although a departure from the traditional separations plant practice of Individual disassembly and removal of each process vessel and service pipe, this technique of treating complete processing units as individual equipment pieces accomplished several objectives. It permitted the processing of small volumes in small equipment without excessive liquid holdup, utilized a minimum of shielded space, and precluded any interference between the 1 on exchange process and the existing operations of fuel processing. 


\section{DISCUSSION}

The production of small quantities of $\mathrm{Pu}^{238}$ by the neutron irradiation of $\mathrm{Np}^{237}$ target elements was begun at Savannah River in 1958, and an 1 on exchange process for the separation of these isotopes from the irradiated targets was demonstrated in a minature pilot plant during the following year. Concurrent with the pllot plant operations, the development of equipment was begun for a plant-scale facility to separate these 1sotopes. This report describes the equipment that was developed to adapt the small-scale ion exchange process to remote operation in the large shielded facilities of the Savannah River fuel processing plants.

Heavily shielded facilities and equipment that was adaptable to remote operation were necessary because the formation of fission products during 1rradiation of the neptunium targets results in gamma radiation levels comparable to those encountered in processing spent reactor fuels. Because some shielded space was avallable in the existing plant facilities, it was economically preferable tc use these facilities rather than to erect a separate processing plant. However, before this space could be effectively utilized, means had to be developed to adapt the small equipment needed by the new process, particularly the ion exchange columns, to operation in a building originally designed for the large equipment associated with reactor fuel processing. At the same time, the new process had to be installed in a manner which ensured complete chemical and operational independence from the existing fuel processing operations.

A brief description of this separation process is presented here to provide the background for the discussion of the equipment.

\section{SIMPLIFIED PROCESS DESCRIPTION}

$\mathrm{Pu}^{238}$ is produced by the neutron irradiation of $\mathrm{Np}^{237}$; an $(n, \gamma)$ reaction on $\mathrm{Np}^{237}$ initially forms $\mathrm{Np}^{238}$, which subsequently $\beta$-decays to $\mathrm{Pu}^{238}$. The irradiated target elements, consisting of $\mathrm{NpO}_{2}-\mathrm{Al}$ compacts containing $\mathrm{Np}^{237}, \mathrm{Pu}^{238}$, and fission products, are "cooled" for several months after removal from a nuclear reactor. These elements are then transferred to a separations plant, where, in shielded facilities, they are dissolved in nitric acid and processed through ion exchange equipment to recover the $\mathrm{Pu}^{238}$ and the unburned $\mathrm{Np}^{237}$. The waste fission products are retalned in underground storage tanks.

Plutonium and neptunium in the (IV) valence state are two of the few metal ions which form stable anionic nitrate complexes that can be strongly absorbed on anion resins from solutions of moderate nitrate concentration. (1) This characteristic permits neptunium and plutonium to be separated from most contaminants, including fission products. Decontamination factors as high as 1,000 are attalnable for each cycle 
of anion exchange. The maximum absorption of $\mathrm{Pu}(\mathrm{IV})$ and $\mathrm{Np}$ (IV) on anion resin occurs in solutions having a total nitrate concentration of about $8 \mathrm{~N}$, and, because the anionic nitrate complex lonizes at low nitrate concentrations, these elements can readily be eluted from the resin by solutions containing about 0.3 molar nitrate ion. Hydrolysis and polymerization are prevented during processing by maintaining a minimum acid concentration of $0.25 \mathrm{M}$. The selection of a specific anion resin for the process is governed by the need for reasonably rapid absorption and desorption kinetics and the need for resins that resist degradation by ionizing radiation. Both "Permutit" SK and "Dowex"-I have been satisfactory in this respect. The detalls of these processes and the reaction kinetics of these resins have been discussed in detall by Tober, et al.(1), Burney and Prohaska(2), and others.(3)

Figure 1 shows the paths of plutonium and neptunium through a process designed to separate them from each other with a cross-contamination of less than $I$ per cent while reducing the concentration of fission products by factors greater than $5 \times 10^{5}$ in each product. Five cycles of anion exchange are required. In the first cycle, both the neptunium and the plutonium are absorbed and thus are separated from aluminum and the bulk of the fission products. In the second cycle, both elements are again absorbed, while again fission products pass through; the plutonium is then selectively eluted. The plutonium next undergoes two successive cycles of anion exchange which constitute the final decontamination and concentration of this product. The neptunium undergoes one additional cycle of decontamination before $1 t$ is transferred to other facilities to be concentrated, converted to the oxide, and fabricated into new target elements.

\section{THE EQUIPMENT FRAME}

Shielded space was avallable within the existing Savannah RIver "canyon"* buildings for the installation of this new process. However, the throughput of the process was to be quite small compared to that of existing "canyon" operations, and small equipment was necessary to minimize inventory and maintain acceptable product concentrations. The remote operation of this small equipment in shielded facilities designed for a process of much larger scale was one of the governing considerations in the design of the processing unit. It was not feasible to supply all of the services required by the new process and

* The term "canyon" as applied locally refers to the heavily shielded building used to house, and supply services to, the process equipment needed for the recovery of plutonium and uranium from spent reactor fuels. A detalled description of this bullding, the design philosophy lised in its development, details of 1ts modular construction, and the manner in which services are supplied to process equipment has been published by Colven, et al.(4) 


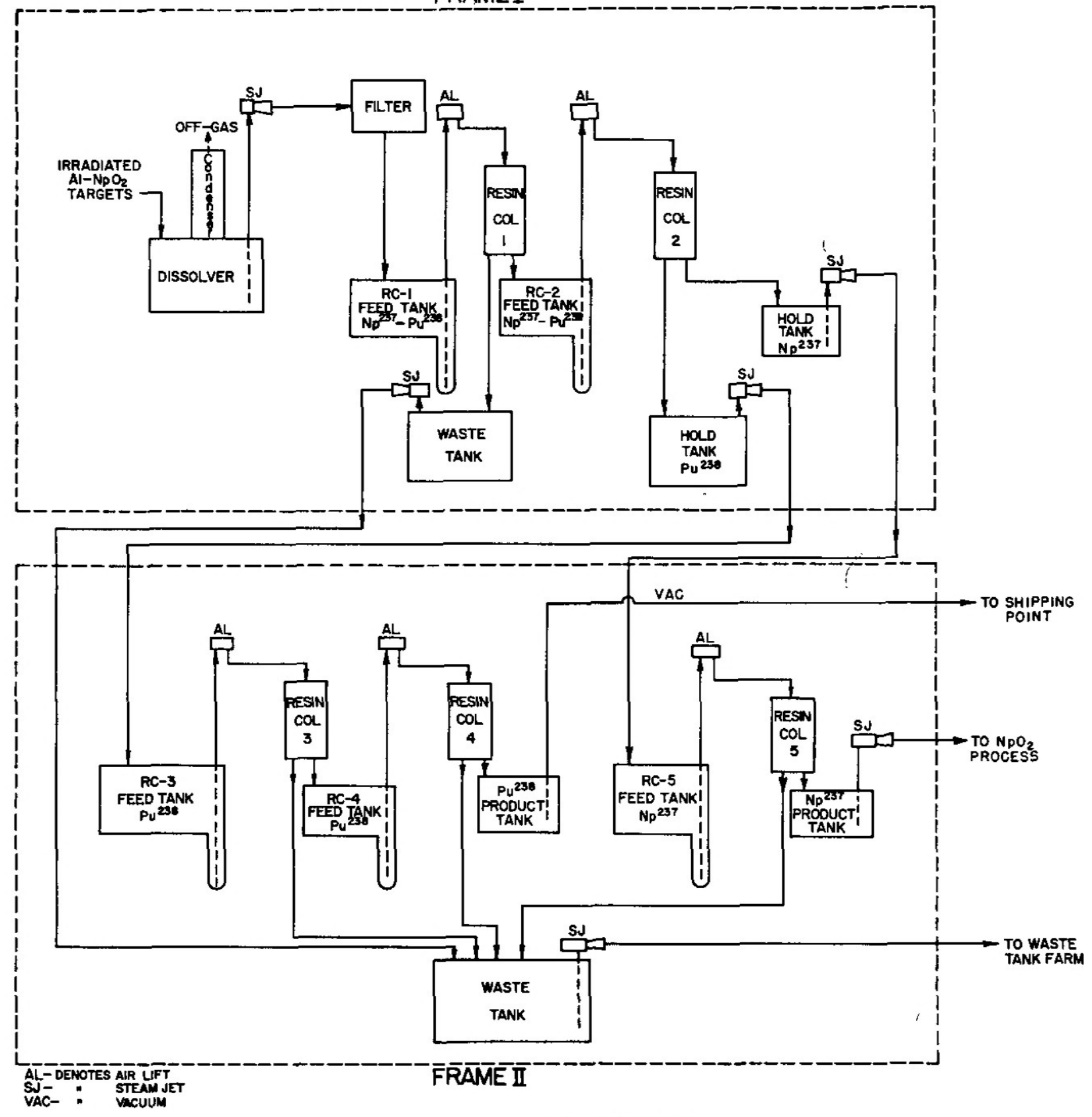

FIG. I PROCESS FLOW DIAGRAM 
still retain the usual practice of individually assembling each equipment plece without holding up excessive volumes of solutions in the process plping and without utilizing a prohibitive amount of shielded space.

A solution to this problem was the development of a "unitized" design in which all of the individual equipment pleces required by the process were mounted in two equipment frames of structural steel, each capable of being installed in or removed from the canyon as a unit. All of the process plping and tankage was permanently mounted within these frames, and only those few critical equipment pieces subject to periodic fallure were designed to be individually removed from the frames and the canyon. This technique represented the minimum departure from the accepted practices of a remotely maintained plant (4) and was equivalent to the installation of completely integrated processing units in space originally designed for a single process vessel.

Each of the two equipment frames required by the process was designed to occupy one module of the canyon, (4) a space about 10 feet square by 17 feet high. As illustrated in Figure l, one frame contained the equipment for the dissolving of the target elements, the initial decontamination cycle, and the partitioning of plutonium and neptunium. The second frame contained the equipment for additional decontamination of the neptunium and plutonium, product collection, and waste handling.

The first frame contalns a dissolver, filter, two ion exchange columns, and five solution adjustment tanks. The process vessels, excepting the Ion exchange columns, are equipped with agitators and probes for the measurement of liquid level and specific gravity; most are also equipped with heating colls, samplers, and temperature instrumentation. Solutions are transferred between vessels elther by steam jets or by ajr lifts. The steam jets, air lifts, ion exchange columns, motordriven agitators, several of the resistance thermometers, and the filter are individually removable from this equipment frame.

The second frame contains three 1on exchange columns and six tanks, all of which are equipped with auxiliaries similar to those in the first frame. The ion exchange columns, steam jets, air lifts, and some thermometers in this frame can also be removed individually.

Each of the equipment frames is a mugged, box-like steel structure containing internal support members for each plece of equipment. Panels are located on the top of the frame for mounting the removable plping and connectors that span the gap between the frame and the supply piping embedded in the shielding walls of the canyon. Figure 2 is a photograph of a typical frame before 1 ts equipment is installed; It shows the heavy structural members used to provide maximum rigidity and to minimize stresses on the permanently mounted piping and tankage. 


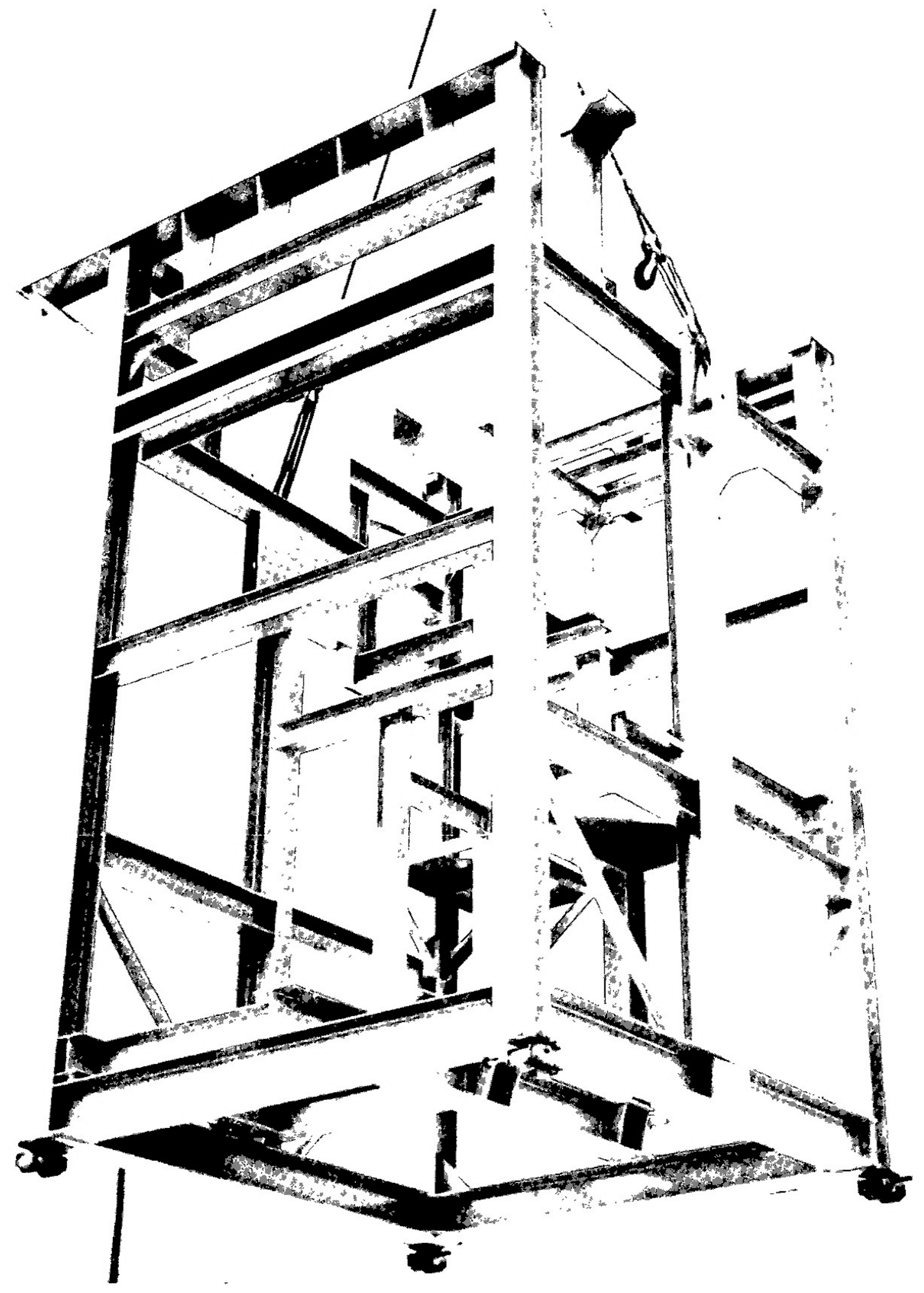

FIG. 2 EQUIPMENT FRAME STRUCTURE 
All of the structural steel has been protected from corrosion by "Amercoat" protective paint, and the bottom of each frame has been completely enclosed with stainless steel to form a sump to collect tank overflow and incldental spillage. This sump completes the chemical isolation of the ion exchange process from the remainder of the canyon operation by ensuring that all spills are reprocessed within the equipment frame.

F1gures 3 and 4 show the plan and elevation views of a completed frame and lllustrate the manner in which the permanent piping and tankage were installed. Plpe sizes were chosen to provide minimum process holdup consistent with reasonable head requirements for solution transfers. Where feastble, lines were sloped to ensure complete drainage. With the exception of the ion exchange columns, the equipment installed in these frames was typlcal of that normally used for remotely maintained installations in the canyon. Descriptions of this auxiliary equipment are summarized in the Appendix.

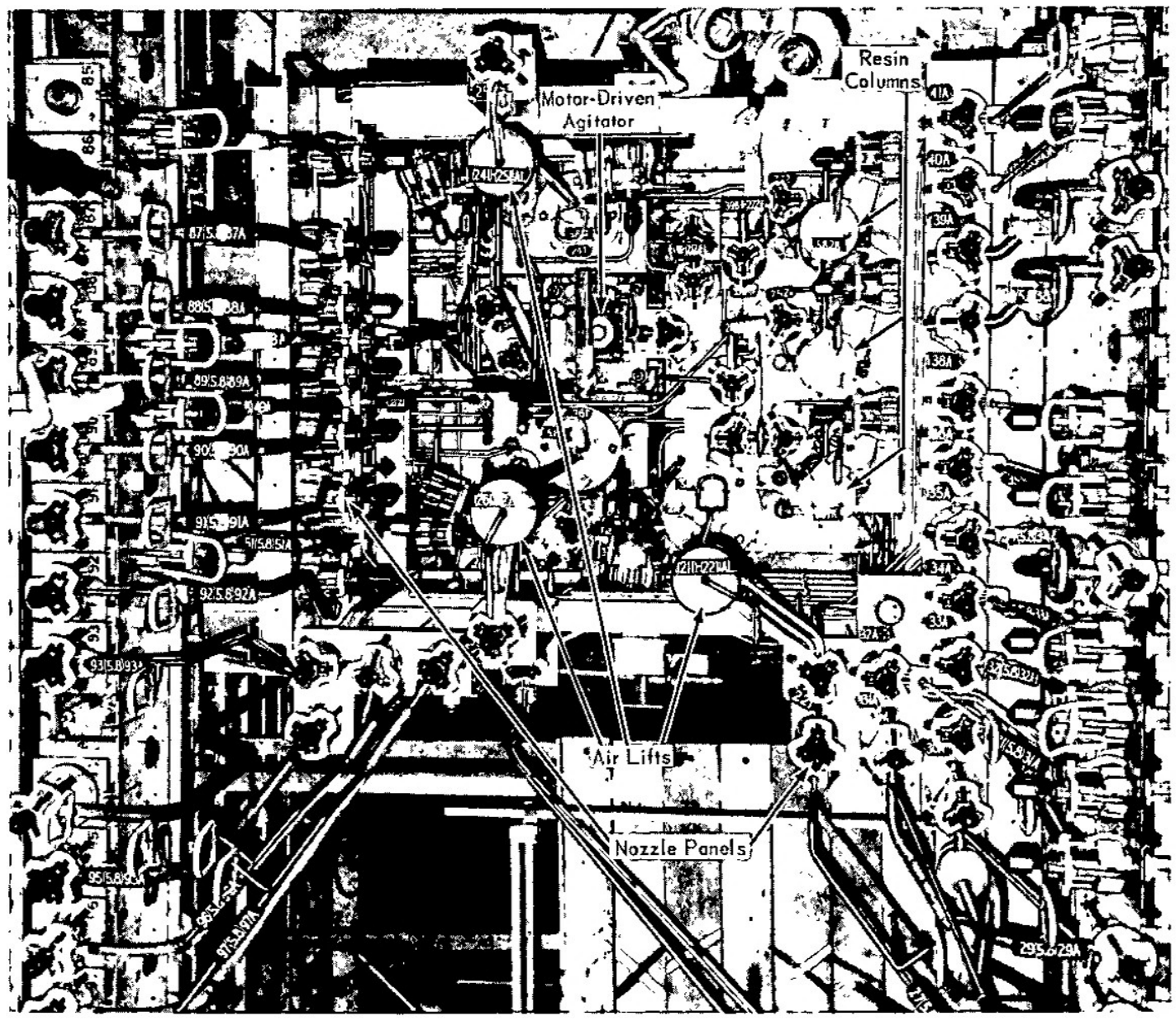

FIG. 3 PLAN VIEW OF A COMPLETE EQUIPMENT FRAME 


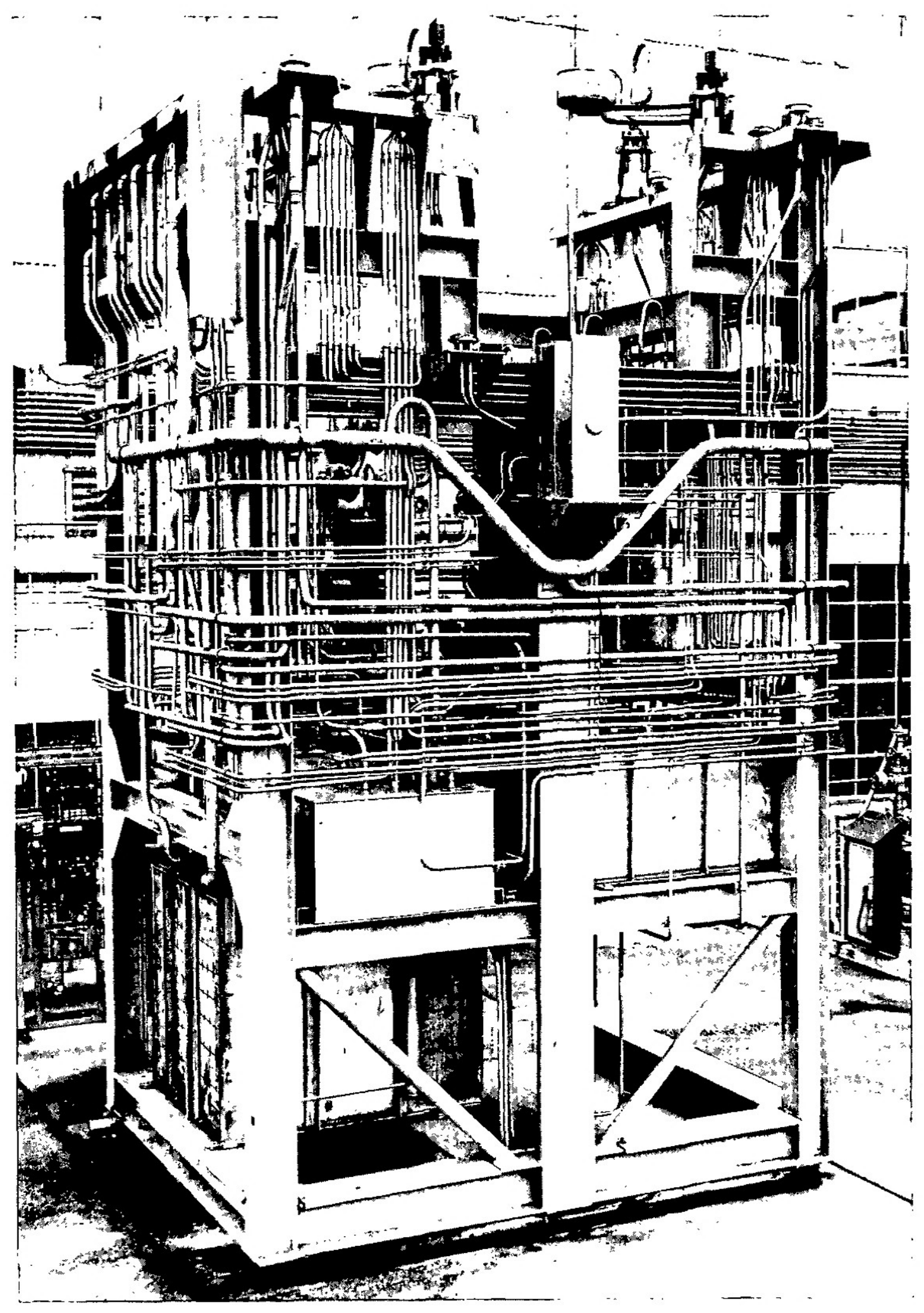

FIG. 4 ELEVATION VIEW OF A COMPLETE EQUIPMENT F RAME 


\section{THE ION EXCHANGE COLUMN}

The principal new equipment plece required to adapt this process to the existing facilities was an ion exchange column in which all operations including replacement of resin could be performed remotely. In this process, relatively frequent resin replacement was required because of the cumulative effects of chemical degradation of the resin in the concentrated nitric acid solutions and the degradation induced by the relatively high radiation fields. In addition, the normal cycilc operations of absorption, washing, elution, and regeneration had to be performed without recourse to complicated valving mechanisms.

Figure 5 shows the ion exchange column developed for this process. Resin is charged and discharged from this column by suspending it as a free-flowing slurry in a solution having a specific gravity comparable to that of the resin. The valving operations are accomplished by a set of two weirs; air pressure can be applied preferentially to elther or both welrs, causing them to act as a three-way valve for the feed and wash, elution, and resin removal operations.

As shown in Figure 5, the ion exchange column is a right vertical cylinder in which the resin is normally contalned as a fixed bed submerged in a pool of the process solution. The resin bed is supported a short distance above the bottom of the column by a stainless steel screen. Process liquid enters the column at the top and is distributed by a splash plate before falling into the liquid pool above the resin. After passing downward through the bed and the support screen, the process liquid leaves the column through one of the two weirs. The first weir, the absorption and wash effluent weir, is positioned at an elevation far enough above the top of the settled resin to ensure that ( 1 ) the resin is always submerged in liquid, and (2) enough solution is present for good agitation of the resin during the resin loading and unloading operations. The second weir, the elution weir, is positioned slightly above the first. The application of a1r pressure to elther welr governs weir overflow so that the two weirs function as a diversion valve. The inlet and outlet lines from the welr boxes take the form of " $U$ " tubes to contain the alr pressure supplied to actuate the weirs.

The resin column is surmounted by a long neck throligh which passes the shaft of a multiple-paddle agitator. The agitator consists of two sets of paddles and a set of splines. The upper paddle agltates and suspends the resin in the column so that resin can be unloaded as a free-flowing slurry. The lower paddle sweeps the support screen during the bed regeneration portion of the ion exchange cycle to clear the screen of any solids which may have accumulated during the prior absorption operations. The splines attached to the agitator shaft in the neck of the column aid in maintaining a free-flowing slurry durling unloading and also serve to break up any resin 


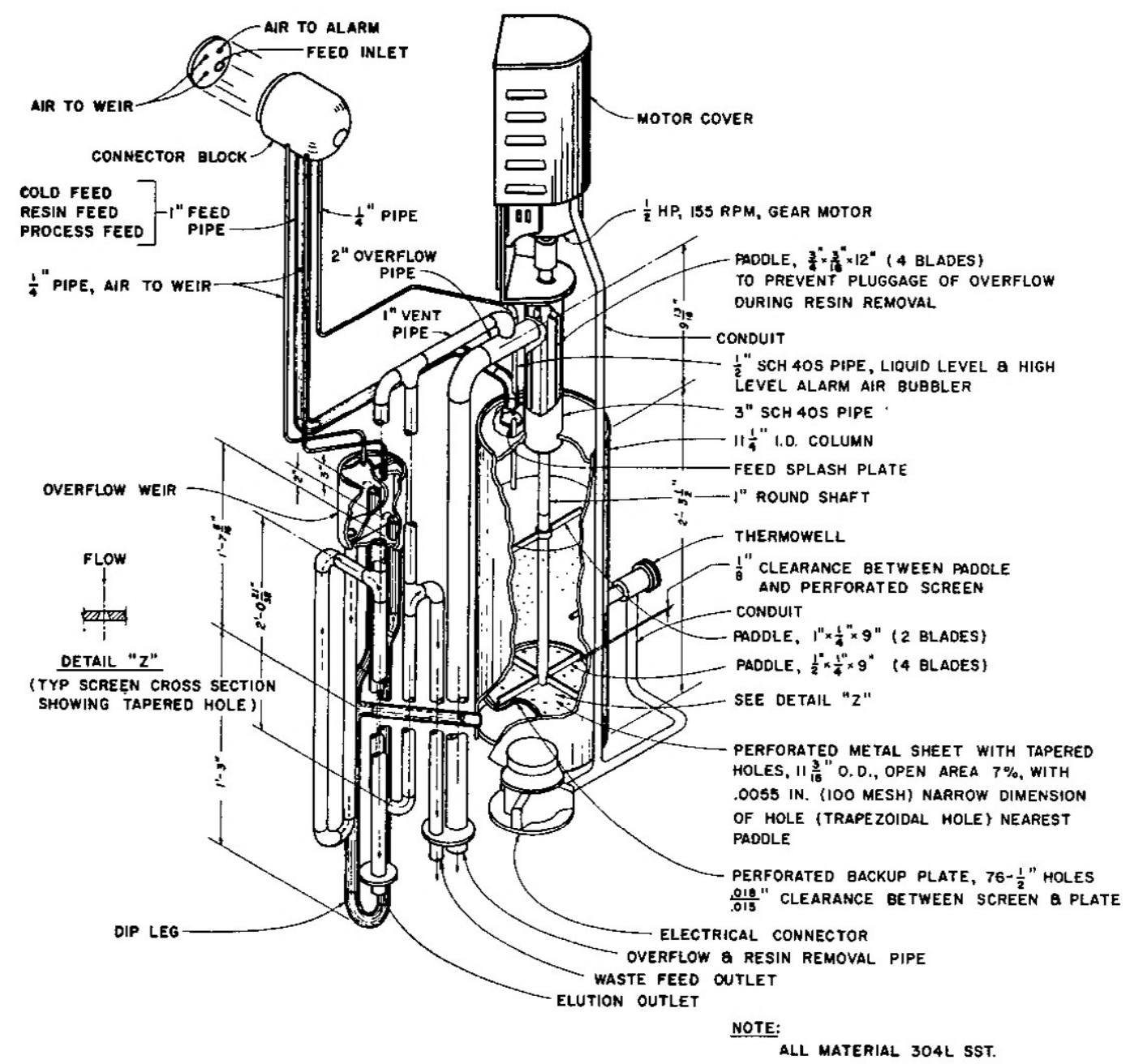

FIG. 5 A TYPICAL ION EXCHANGE COLUMN

agglomerates that may have formed under the exposure of the resin to radiation and chemical degradation.

Resin is fed to the column as a slurry in a solution having a spec1fic gravity equal to that of the resin. The "loading solution" passes through the screen and overflows the effluent weir while the resin is retained in the column by the screen. The agitator is in operation during part of the loading operation to minimize pressure drop through the bed.

Resin is unloaded from the column by applying air pressure to both weirs and feeding to the column a solution having a specific gravity the same as that of the resin. With the agltator running, the resin slurry rises in the neck of the column and passes out of the column through an overflow pipe in the neck. During the operations of absorption, washing, and elution the column acts as a fixed but unrestrained bed, while during regeneration the resin is agitated to remove accumulated solids and to redistribute the resin so that ali resin receives approximately equal radiation exposure. 
The three liquid effluent lines from the column (feed effluent, elution effluent, and overflow) mate with funnels and pipe which are mounted within the frame to direct the solutions to the proper collection tank. The resin slurries that are removed from each column enter a common header that terminates in a waste collection tank from which the resin is eventually transferred to the waste handling system of the building.

The ability of this column to clear itself of accumulated solids makes it useful in applications where filtration is impractical; in these instances the agltator can be operated during the feed cycle. The bed performance no longer follows the typical breakthrough characteristic of fixed bed ion exchange; however, it can be used in an efficient manner by procedures described by Prout $(5)$ and Caracciolo $(5)$. Caracciolo has published a description of the operation of this column as an "agitated bed" in which the effects of channeling, resin attrition, loading and unloading techniques, permissible flow rates, and specific gravity of the process solutions are discussed in detall.

\section{THE PROTOTYPE UNIT}

A completely equipped prototype of one frame was constructed to demonstrate the feasibility of the concept and the reliability of the individual plece of equipment when assembled in a complete unit. This prototype duplicated all features necessary to the remote operation in the Plant process. All of the transmitting and recording instrumentation was included to ensure that no instrument difficulties would be encountered during Plant operation. The prototype unit was subjected to extensive operability tests, determinations of the sensitivity of instruments to process changes, and flow and volumetric calibrations. In terms of over-all equipment utilization, the equivalent of several months of operation was accumulated during this demonstration. Some of the information developed during the demonstration has been included in the Appendix.

This prototype frame was instalied as part of an ion exchange recovery process for the decontamination of the $\mathrm{Np}^{237}$ that is recovered from the waste streams of the natural uranium fuel processing plant. As such, it represented the third frame to be installed in the plant. The prototype frame was essentially a duplicate of one of the frames required for the neptunium target process; 1.e., it contained three ion exchange columns and essentlally the same process tankage and transfer equipment as the frame required for final decontamination of $\mathrm{Np}^{237}$ and $\mathrm{Pu}^{238}$. To ensure that all equipment was operable and reliable, each of the target processing frames was similarly tested before 1 t was installed in the plant.
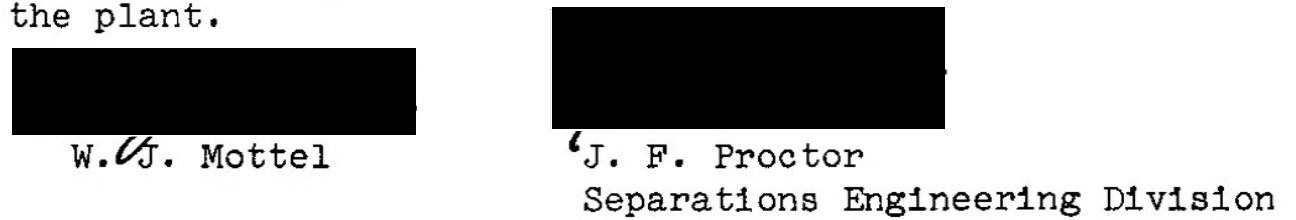


\section{APPENDIX}

\section{DESCRIPTION OF AUXILIARY EQUIPMENT}

Descriptive information is presented below on the design of individual equipment pleces developed for the process. The descriptions are typlcal for each frame that has been constructed.

\section{SERVICE PIPING}

The services required included water, steam, electric power, chemical solutions, service air and instrument air. All of these services were supplied to the frames through existing lines embedded in the canyon shielding wall(5). Connections to the frames were made by removable pipe and electrical "Jumpers" that connected nozzles on the embedded pipe with corresponding nozzles mounted on panels at the top of the frame (see Figure 3). From the nozzle panels the services were distributed by permanently installed piping and electrical conduit.

Initially, there were not enough embedded lines to supply all of the services required by the frames; however, the number of individual service lines was increased by drawling bundles of as many as six small (1/2-1nch) tubes through the existing 3-inch pipes embedded in the canyon shielding walls. A total of fifteen of these "tubing pulls" were made. Some were through embedded pipe sections up to 15 feet long that contalned several irregular bends. The force required to draw a bundle of six tubes was of the order of 2,000 pounds, while a maximum of 5,000 pounds was required to form a tight seal between the new nozzle of the bundle and the existing nozzle on the embedded pipe. It is expected that this technique will be applicable to other canyon applications.

\section{PROCESS VESSELS}

All of the solution adjustment and hold tanks were of a flat-bottomed rectangular design to provide the maximum tankage volume. Consistent with canyon practice, none of the tanks were equipped with bottom drains and therefore each operates with a small nonremovable liquid heel. All service lines enter through the top of the vessel to minimize the number of welded junctions continuously exposed to process solution. A complete X-ray examination was made of each tank and pipe weld, and all tanks were plckled for 24 hours in hot nitric acid to ensure that a welded jolnt would not fall prematurely.

With a few exceptions, tanks were equipped with agitators, probes to measure liquid level and specific gravity, sample lifts, temperature measuring devices, and colls for cooling and heating the vessel contents. Alr spargers were used for agltation in all tanks except those handling resin slurries; electrically driven propeller agitators were provided in those tanks which handled resin discharge from the columns. 
The neptunium target dissolver was a scaled-down version of a dissolver used in the processing of natural uranium reactor fuels(4). It was also equipped with liquid level and specific gravity probes, pressuresensing taps, and an off-gas condenser. A filter, which was individualiy removable from the frame, was provided to remove solids, principally silica, from the dissolver solution. Figure A-1 shows the filter and Figure $\mathrm{A}-2$ shows the dissolver.

Solution transfers between tanks were made with both alr lifts and steam jets. In those tanks containing alr lifts, a 5-foot-long, 4-inch-diameter well was mounted in the bottom of the tank to provide the necessary submergence for operation of the lift. Steam jets were used for transfers between frames and for recycle of material within a frame, while air lifts were used to feed all columns. Steam jets were used to transfer waste solutions and neptunium product; vacuum lifts were used for transfers of plutonium product and samples.

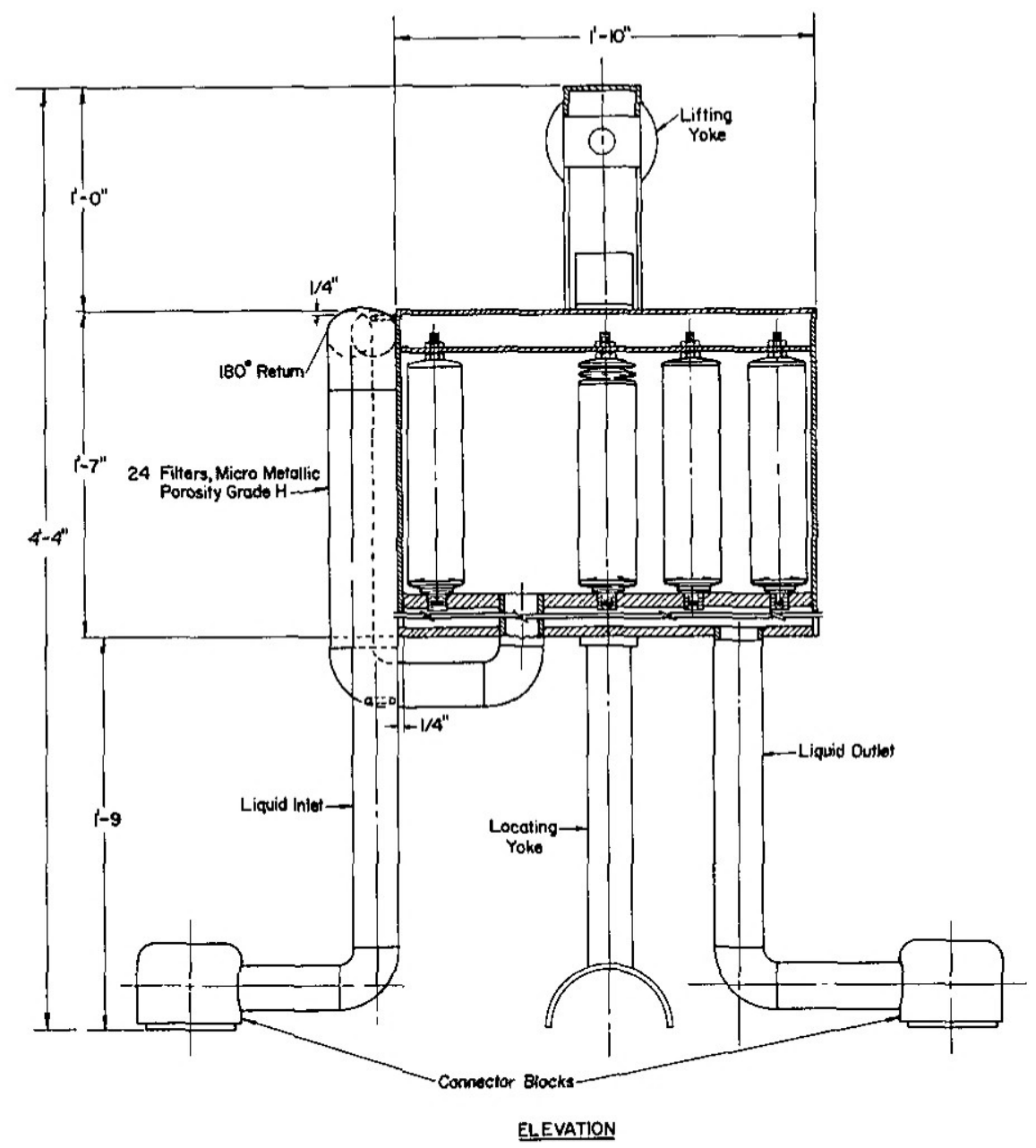

FIG. A-I FILTER 


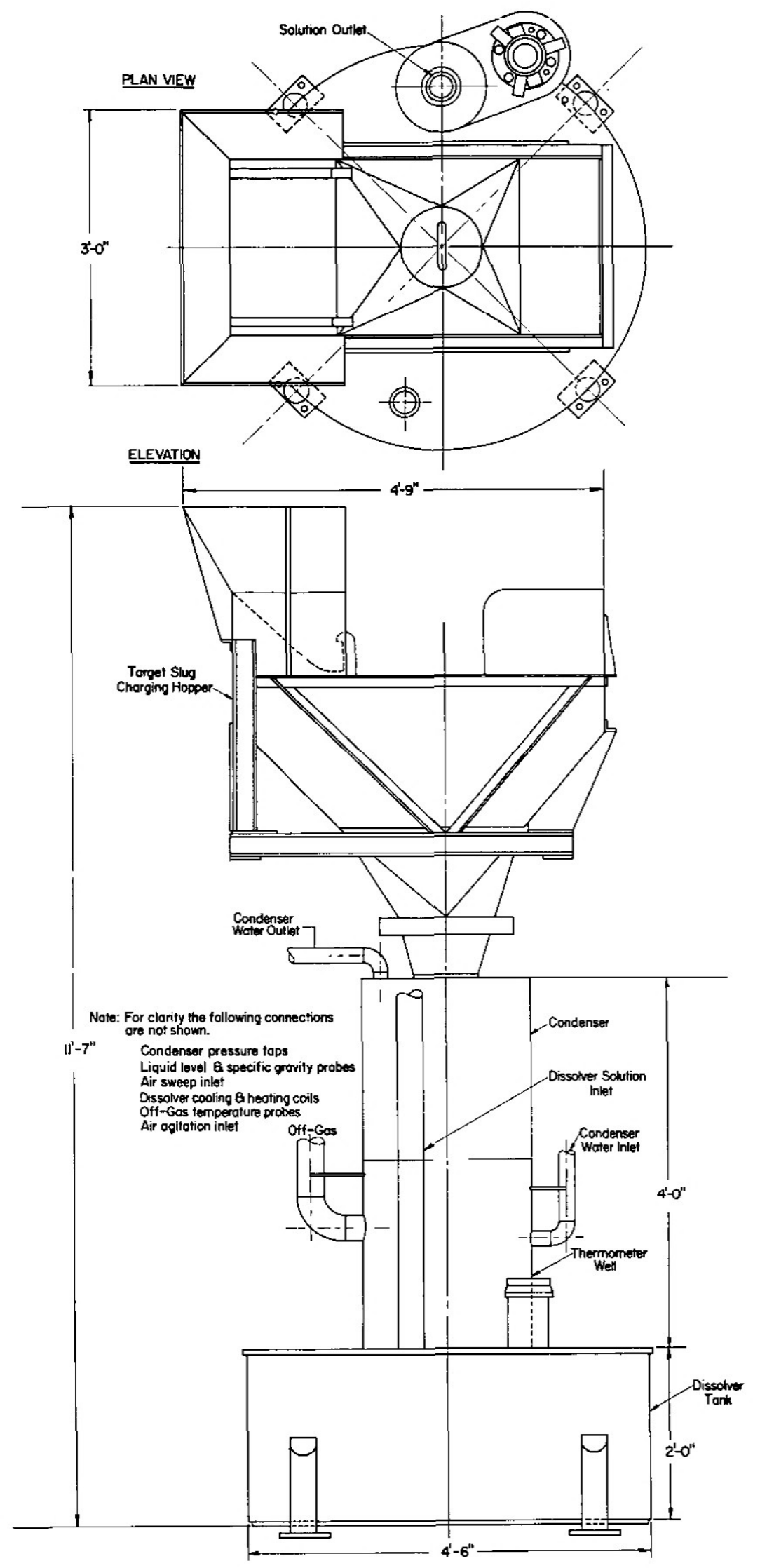

FIG. A-2 TARGET DISSOLVER 


\section{AIR LIFTS}

The feed rate of solution to an ion exchange column is governed principally by the kinetics of the resin, the size of the column, and the concentration of the absorbable species. In this process these factors place a range on feed rate of between one and three liters per minute. A1r lifts were chosen for this service because of their simplicity (no moving parts) and their demonstrated ability to handle resin slurries without pluggage(7). Steam or air jets of a suitable capacity would be susceptible to pluggage of the nozzle throat, while mechanical pumps would be subject to wear and leakage.

Figure A-3 show a typical air lift. The air flows required to produce a range of liquid flowis from one to three liters per minute range from 0.5 to 2 scfm, and changes in liquid level and specific gravity of the feed solution produce no more than a lo\% change in liquid flow at any given air flow. Monltoring of the liquid flow rate in the frames is based upon the tank depletion indicated by the liquid level instrumentation.

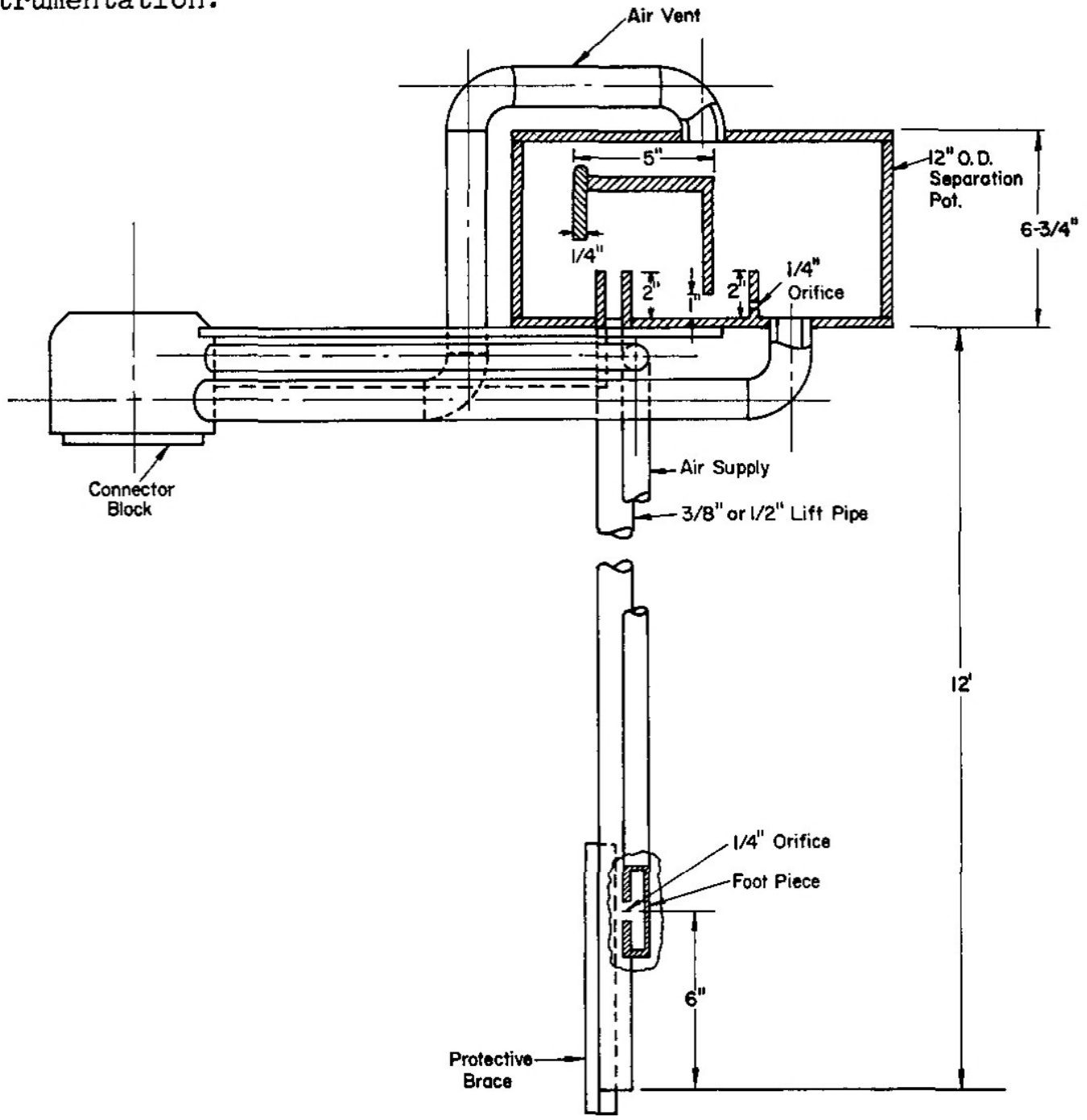

FIG. A-3 TYPICAL AIR LIFT AND SEPARATOR 
The recelving chamber of the top of the lift shown in Figure A-3 was required to provide a disengaging space for liquid entrained in the air stream and to provide a small liquid holdup to damp the inherent surging action of these lifts.

\section{VESSEL VENTING AND ENTRAINMENT}

In compliance with accepted separations plant practice, all of the process equipment within each frame was connected to the vessel vent system of the canyon. Th1s system maintains a one- to two-inch negative pressure differential between process equipment and the canyon atmosphere to minimize the release of airborne activity within the canyon. To reduce the number of individual connections required, each process vessel within the frame was connected to a common vessel vent header mounted permanently within the frame. This header then made a single connection with the common vessel vent system of the canyon. The ion exchange columns, however, were not connected directly to this vent system. Instead, in order to simplify removal of the columns from the frame, air sweeps from the canyon into the frame equipment were provided across each of the openings in the column. Also in accordance with established practice liquid seals were included in all process lines that entered the frame from a service area of the canyon building. This technique minimizes the possibility of active materials being released in areas occupied by personnel and is considered mandatory for operation of the separations plants.

Tests were made on the prototype equipment frame to establish the level of entrained activity to be expected in the vessel vent system during the operation of air lifts and air spargers. The measured entrainment levels were consistently below 2 ppm at air flows of 1 to 1.5 pounds per minute $(15 \mathrm{cfm}$ ) in the vent header on the frame. These results indicated that the air lift separators (Figure A-3) and the vent header were efficient entrainment separators and that no difficulties would be encountered with excessive alrborne radioactivity. 


\section{BIBLIOGRAPHY}

1. Tober, F. W. "Concentration and Purlfication of Uranium, Plutonium, and Neptunium by Ion Exchange in Nuclearly Safe Equipment". Proc. U.N. Intern. Conf. Peaceful Uses Atomic Energy. 2nd, Geneva, 17, $57^{4-84(1958) \cdot P / 520}$

2. Burney, G. A. and C. A. Prohaska. The Recovery of $\mathrm{Np}^{237}$ and $\mathrm{Pu}^{238}$ from Irradiated Neptunium Oxide (Title Classified Secret). E. I. du Pont de Nemours \& Co., Savannah River Laboratory, Aiken, S. C. AEC Research and Development Report DP-417, 14 pp. (November 1959) (Secret).

3. Burney, G. A. Anion Exchange of Neptunium in Nitrate Solutions (Title Classified Secret). E. I. du Pont de Nemours \& Co., Savannah RIver Laboratory, Alken, S. C. AEC Research and Development Report DP-531, 20 pp. (December 1960)(Secret).

4. Colven, T. J., et al. Processing of Irradiated Natural Uranium at Savannah River. E. I. du Pont de Nemours \& Co., Savannah River Laboratory, Alken, S. C. AEC Research and Development Report DP-500, $606 \mathrm{pp}$. (August 1960)(Secret).

5. Prout, W. E. and L. P. Fernandez. Recovery of Neptunium from Purex Waste by an Agitated Bed of Anion Exchange Resin (Title Classifled Secret). E. I. du Pont de Nemours \& Co., Savannah River Laboratory, Aiken, S. C. AEC Research and Development Report DP-453, 18 pp. (February 1960)(Secret).

6. Caracciolo, V. P. Anion Exchange in a Large-Scale, Agitated Bed. E. I. du Pont de Nemours \& Co., Savannah RIver Laboratory, Aiken, S. C. AEC Research and Development Report DP-624, (to be issued).

7. Kearsley, G. W. T. Use of an Air Lift as a Metering Pump for Radioactive Solutions. Oak Ridge National Laboratory, Tenn. AEC Research and Development Report ORNL-2175, 35 pp. (October 1956). 
REPORT DATA SHEET

TECHNICAL DIVISION

\section{SAVANNAH RTVER LABORATORY}

Report Number

DP -620

S) C U Approved by

secón

Author(s) J.F. Proctor.

T1tle The Adaptation of an Ion Exchange Process To Remote Operation

In A Radiochemical Separations Plant

Division Separations Engineering Division

Indicate known prior art

Approval (Introduction, Summary, Cover Letter)

\begin{tabular}{l|l|l|}
\hline Section D1rector ow Laboratory Director & si \\
\hline
\end{tabular}

\section{$6 / 19$}

Manuscript Approval (MS)

Reproduction Copy Approval (RC)

Recommended for Publication
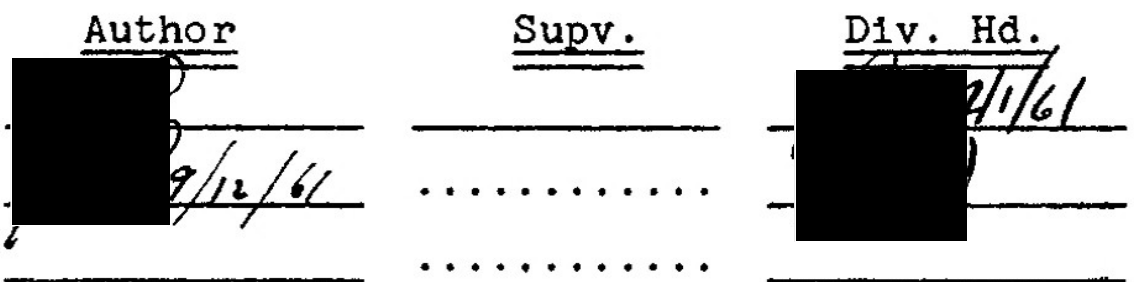

Publication in

Presentation at

\section{Special TO BE COMPLETED BY TIS}

Category

classification of Abstract

Classification of Title रि:?

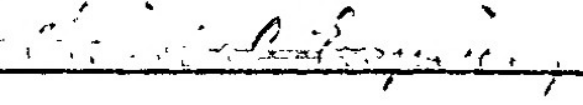

$\frac{k}{k}$

Transmittal Letter DP $=1 t$ TL

No. of copies for Distribution

Internal

TID-4500

M-3679

(S) $\mathrm{C}$

Special

Total

$$
\begin{aligned}
& \text { Sitht } \\
& \text { Suth }
\end{aligned}
$$

\section{Approved by}

Total Pages

Price 
Tromitent Divisto:

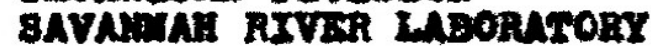

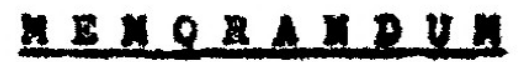

Tot C.H.J.MAm

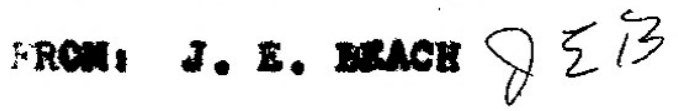

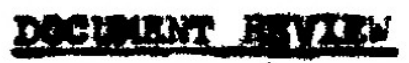

Babuent,

Boprt DP-62O

$21+1=8$

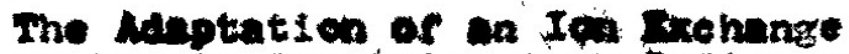

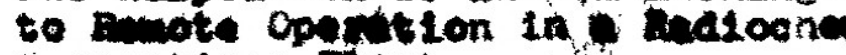
be buretions Mant

Authore:

W. J. H.ttel and J.F. Frostos

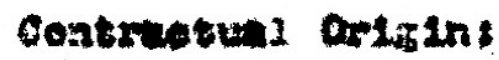

$\ln (07-6)-1$

Eoptrintor 25. 1961

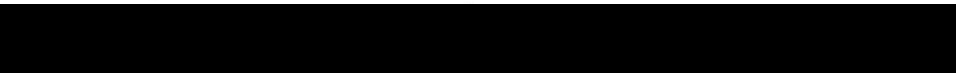

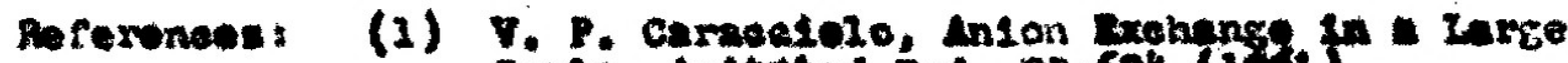

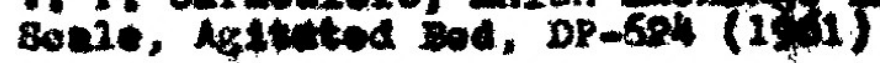

(2) Propubltifutica soviow of (1) anted sune 26, 1961

Wo itew were noted that, In my opinigh, should be anlied ye the attention of the $A$ for petent oonsidistion.

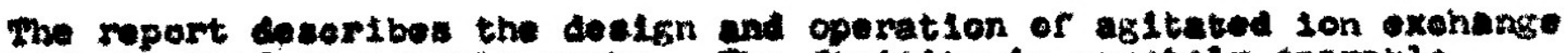

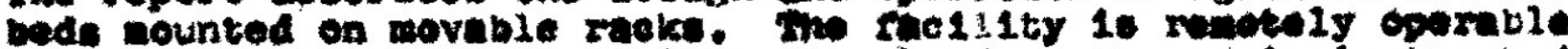
ineluding the trepe of leading no untoding the wein in in bods.

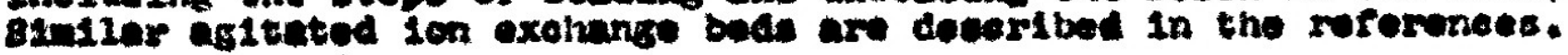




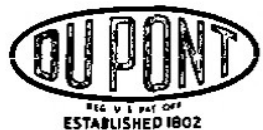
E. I. du Pont de Nemours \& Company

Aiken, South Carolina

(TEL. \& TEL. ADDRESS, AUGUSTA, GA.)

EXPLOSIVES DEPARTMENT

SAVANNAH RIVER LABORATORY

Mr. P. J. Hagelston, Director (2)

Technical and Production Division

Savannah River Operations office

U. S. Atomic Energy Commission

Post office Box A

Alken, South Carolina

Dear Mr. Hagelston:

\section{PROPOSED PUBLICATION - DP - 620}

Attached for review are three coples of the following classifled report:

The Adaptation of an Ion Exchange Process to Remote Operation In a Radiochemical Separations plant by W.J. Mottel and J. F. Froctor

Please contact my offlce if you have any comments. The report w11l be released when approval is recelved, but not until after 14 days from the date shown above.

$$
\begin{aligned}
& \text { Yours very truly, } \\
& \text { Original signed by } \\
& \text { W. P. Overbeck } \\
& \text { W. P. Overbeck, Director } \\
& \text { Savannah River Laboratory }
\end{aligned}
$$

SWO'R/ pa

Enc .

OSR-24 Al32 (Rev. 7/61)

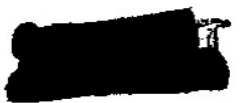




\section{$D P-620$}

\section{PRELIMINARY DISTRIBUTION}

\section{Copy No.}

1-3. P. J. Hagelston

4. S. A. McNeight

5. L. C. Evans - H. Worthington

6. W. P. Overbeck - C. W. J. Wende J. O. Morrison

7. J. W. Morris

8. W. E. Winsche - J. F. Proctor

9. W. J. Mottel

10. TIS File Record Copy
SRoo, Aiken, S. C.

Wilmington AED

Savannah River Laboratory 11

11

n

If
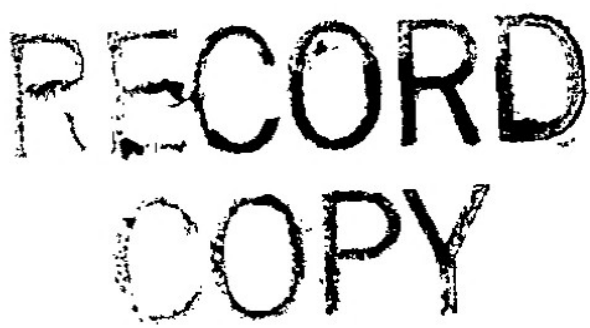

DC NOT ACL

FHOM FIL: 


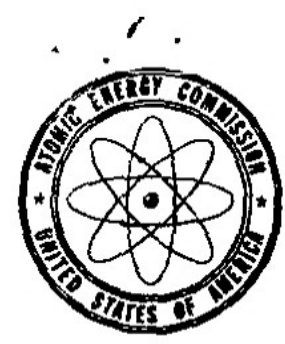

UNITED STATES

ATOMIC ENERGY COMMISSION SAVANNAH RIVER OPERATIONS OFFICE

P. O. BOXA

AIKEN, SOUTH CAROLINA

TI:NWP

September 21, 2961

Nr. W. P. Orerbed, DIrector

Savunnah RIver Jaboratory

I. I. Cont de Nernoure gart Compeny

Atren, South Caroling

Attention: J F. Noxrie, Darector

Separations and Sexvices Section
Dear H. Overbeck:

Wo heve reviewed the following

document trins-

mitted by your lettor of September 19, 1961 , and this

office bas no objection to its proposed release:

$$
\begin{aligned}
& \text { DP-620 - "The Adaptation of an Ion Trohnnge Process } \\
& \text { to Temote Operation in a Madiochemical } \\
& \text { Separations Plant" - by W.J. Sottel and } \\
& \text { J. F. Proctor }
\end{aligned}
$$

Your office was so not111ed by telephone this date.

Very traly yours,

Paul J. Hagelaton, Director

Technioel s Production Division

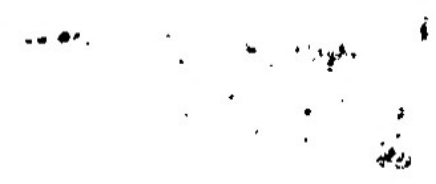




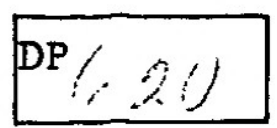

DP REPORT PROCESSING FORM

(Perform last 1tem checked)

Author

$-[i$

Date

1. PRINT SHOP: Reproduce /(/) blackline copies

of report. No. of Pages 11

1) coples of transmittal letter

itcopies of preliminary distribution page

Send approval copy of report, transmittal letter, and preliminary
distribution page with photocopy and Form to Editing. Date to Editing $9 / 13$

2. EDITING: Review Approval Copy and forward with Document Review and

Proposed Pub. letter for Final Review.

To $9 / 15$ From $9 / 1$,

Send approved copy, Document Review, Proposed Pub. Letters and Form to

Print Shop.

3. PRINT SHOP AND DOCUMENT SECTION:

Bind and issue 10 preliminary (blackline) copies

coples

Send blackline Record Copy with Form to Editing.

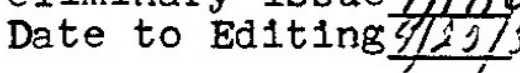

4. EDITING: Collect corrections and releases. SAM ... AEC $9 /=1 /$ Author $10 / 1 \% /$ Notify Document Section to recall Preliminary Cop 1es. Date Notified/o/16/: Send corrected blackline Record Copy, corrected photocopy, Internal

Distribution master, and Form to Print Shop.

5. New Negative: $P \cdot 7$
PRINT SHOP:

Make corrections and print 1, coples of report.

No. of pages 22 Price $\$$ Copies of Internal Dist. 11st 77

Assemble printed Record Copy and send with blackline Record Copy,

corrected photocopy, and Form to Editing.

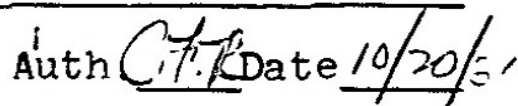

Date to Editing

6. EDITING: Review printed Record Copy. Return printed Record Copy with Publication Forms and Form to Print Shop.

7. PRINT SHOP AND DOCUMENT SECTION:

Bind and issue report:

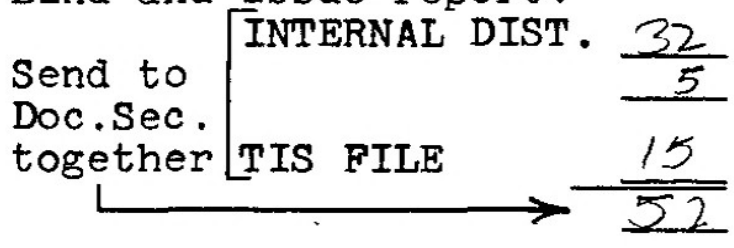

EXTERNAL DIST. Total

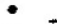

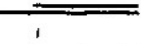

with TL

without TL( 5 SROO, without TL

coples and 6 extra copies of TL coples without TL coples of report
Int. Issue Date $10 / 25 / 61$

Auth $1,7 R_{\text {Date } 10 / 24 / 61}$

Ext. Issue Date $10-25-6 /$ 
8. EDITING: Send file folder to Document section, including:

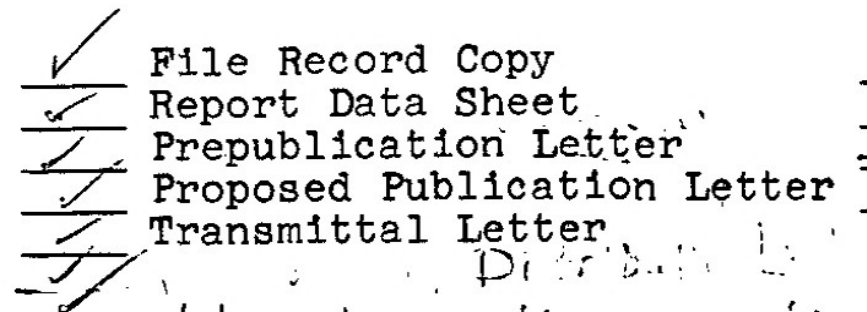

Interne S. A. McNe1ght's Approval Letter

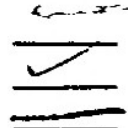
AEC Approval Letter 2 T/. n Publication Form r. lase $_{\text {e }}$ DP Report Processing Form

Date $\operatorname{Rec}^{\prime} \mathrm{d}$

9. DOCUMENT SECTION: Add external distribution list to file folder and issue File Record Copy Folder to swo.

Date to File 
E. I. du Pont de Nemours \& Company incopPoRATED

Alken, South Carolina

(TEL, a TEL, MDDRESS, AUGUSTA, GA.),

EXPLOSIVES DEPARTMENT

SAVANNAH RIVER LABORATORY

$*$

H. WORTHINGTON, DIRECTOR

TECHNICAL DIVISION

EXPLOSIVES DEPARTMENT - AED

WIIMINGTON

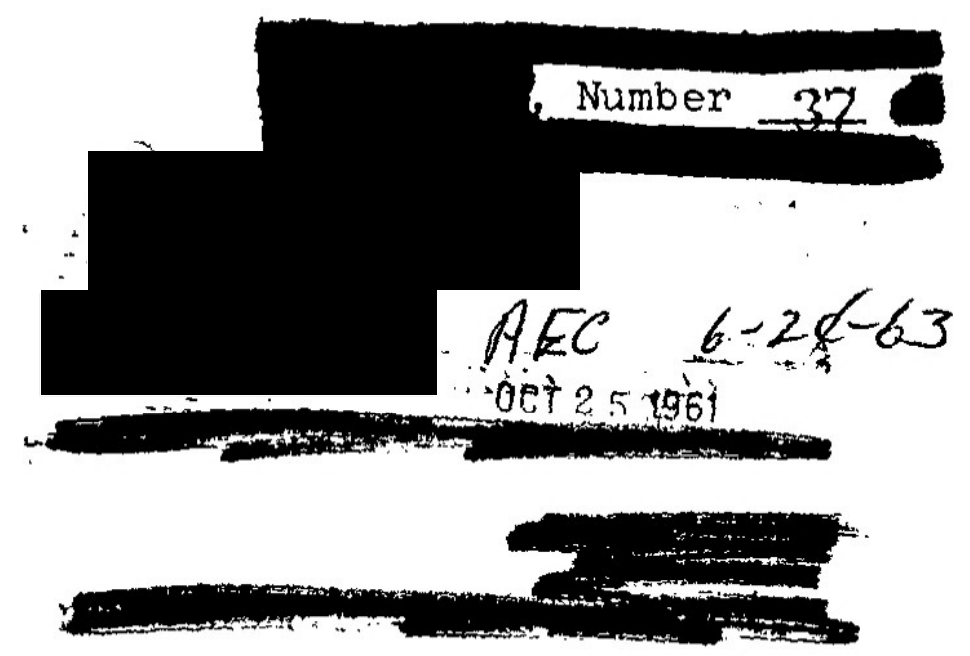

DP-620, THE ADAPTATION OF AN ION EXCHANGE PROCESS TO REMOTE OPERATION IN A RADIOCHEMICAI SEPARATIONS PIANT

by W. J. Mottel and J. F. Proctor

This report describes the successful application of the "frame" concept to the equipment for processing $\mathrm{Np} 237$ and $\mathrm{Pu} 238$ by ion exchange with anion resin. When we were requested by the Atomic Energy Commission to provide fac1lities for this processing, it was realized that anion exchange could be used as the basic process but that the service conditions were entirely different from previous experience. Up to this tilme ion exchange had been used only in gloved-box cabinets in low radiation fields. In this new application, remote operation would be required because of the high gamma radiation and the resin iffe would be very short because of the high alpha radiation.

A "frame", which consists of a structural unit containing several vessels and interconnecting plping, fits into the canyon space originaliy provided for a single vessel. Tanks are permanently Installed within the frame, but resin beds and similar equipment can be individualiy replaced by remote techniques. Similarly, sampler I1nes and bubblers are permanently Installed, but the a1rlifts used for liquid transfers can be replaced remotely. The achievement of the proper compromises between increased complexity and versatility and the selection of mutually compatible means of agltation, Ilquid transfer, control, and the like are described in the attached report.
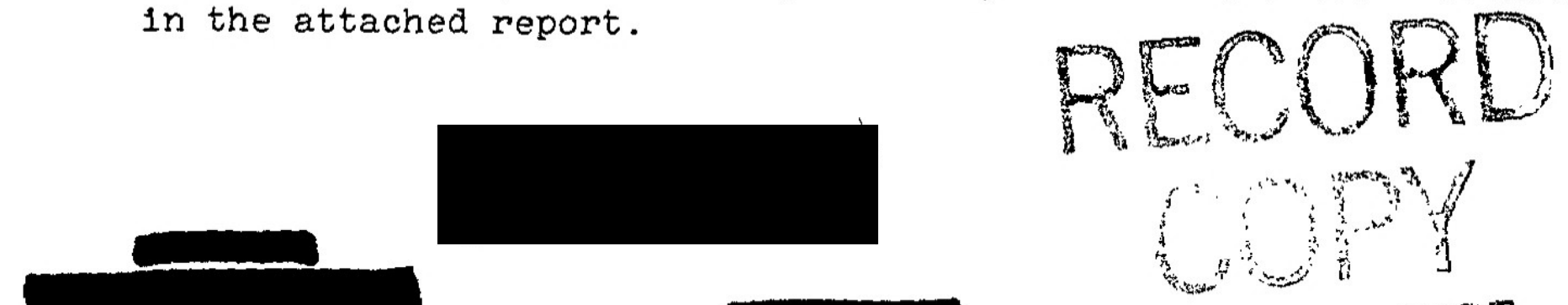
It appeared that the "frame" concept should be feasible and that, if successful, it would be a low cost system that could be put in operation earlier than the alternatives, all of which required building additions. Accordingly, the Technical Division was requested to design and build two of these frames and demonstrate the feasibility of this concept. When this work was successfully completed, the Plant system using frames was accepted as the basis of design. The plant units, which include the two bulit on the Technical Division project, were exhaustively tested at the Semiworks before being installed in the Plant. The degree of success of these units in Plant operation will indicate the extent to which this concept should be applied to other processing requirements.

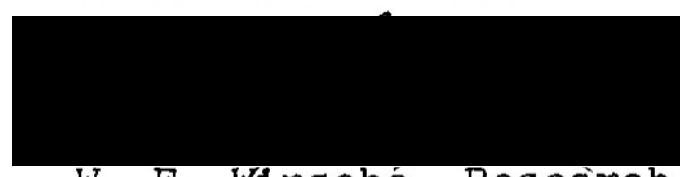

W. E. Yinsché, Research Manager Separations Engineering Division 
